Original Article

\title{
Replacement level of rubber seed cake for soybean meal on the growth of Japanese quail
}

\author{
Nível de substituição do bolo de semente de borracha pelo farelo de soja no \\ crescimento da codorna japonesa
}

\author{
G. L. Nnadia, V. C. Simeon-Ahaotub, P. De los Ríos-Escalantec,d (1), and E. O. Ahaotu ${ }^{\mathrm{a} *}$ (1) \\ aImo State Polytechnic Umuagwo, Department of Animal Production Technology, Umuagwo, Nigeria \\ ${ }^{\mathrm{b} G r e g o r y ~ U n i v e r s i t y, ~ D e p a r t m e n t ~ o f ~ M i c r o b i o l o g y, ~ U t u r u, ~ A b i a ~ S t a t e, ~ N i g e r i a ~}$ \\ ‘Universidad Católica de Temuco, Facultad de Recursos Naturales, Departamento de Ciencias Biológicas y Químicas, Temuco, Chile \\ dUniversidad Católica de Temuco, Núcleo de Estudios Ambientales, Temuco, Chile
}

\begin{abstract}
A four-week feeding trial on the simultaneous replacement of 0 to $50 \%$ of soybean meal and 0 to $100 \%$ of soybean oil on the growth performance, carcass composition and profitability was conducted using 45 randomly chosen one-week-old growing Japanese quail. The five experimental diets were; $\mathrm{D}_{0}=$ Diet containing $20 \%$ soybean meal and $4 \%$ soybean oil (control diet), $D_{1}=$ Diet, where $12.5 \%$ of soybean meal and $25 \%$ of soybean oil has been replaced by RSC; $\mathrm{T}_{2}=$ Diet, where $25 \%$ of soybean meal and $50 \%$ of soybean oil has been replaced by RSC; $\mathrm{T}_{3}=$ Diet, where $37.5 \%$ of soybean meal and $75 \%$ of soybean oil has been replaced by RSC; $\mathrm{T}_{4}=$ Diet, where $50 \%$ of soybean meal and $100 \%$ of soybean oil has been replaced by RSC. Results demonstrated that in raw rubber seed the proportion of kernel to hull is 64: 36. Proximate components of the boiled and sundried full fat rubber seed kernel (RS) were, moisture = $96.6 \%, \mathrm{ME}=5305 \mathrm{kcal} / \mathrm{kg} \mathrm{DM}, \mathrm{CP}=17.6 \%, \mathrm{EE}=51.05 \%, \mathrm{CF}=8.5 \%, \mathrm{NFE}=18.25 \%$ and $\mathrm{Ash}=4.6 \%$. The body weights of the birds at 35 days of age in all dietary treatments were statistically similar. The feed intake of the quail among different dietary groups was varied significantly $(\mathrm{p}<0.05)$ and there was a tendency of decreasing the feed intake at $25 \%$ and above inclusion level of RSC. The body weight gain and FCR were also statistically similar in all dietary groups. The feed cost and total production cost $/ \mathrm{kg}$ BW of quail was also found to become steadily higher $(\mathrm{p}>0.05)$ at higher RSC inclusion level. The muscle development was found to better at lower (\%) RSC level, whereas the organs were enlarged at higher RSC inclusion. Results on the majority of the production parameters, and economics and carcass yield parameters suggested that the simultaneous replacement of maximum 50\% soybean oil $25 \%$ soybean meal by processed RSC might be suggested, particularly, there will be a crisis in the availability of these two ingredients.
\end{abstract}

Keywords: rubber seed cake, soybean meal, growth performance, japanese quail.

\begin{abstract}
Resumo
Um ensaio de alimentação de quatro semanas na substituição simultânea de 0 a $50 \%$ de farelo de soja e 0 a $100 \%$ de óleo de soja no desempenho de crescimento, composição de carcaça e lucratividade foi conduzido usando 45 codornas japonesas em crescimento com uma semana de idade escolhidas aleatoriamente. As cinco dietas experimentais foram: D0 = Dieta contendo $20 \%$ de farelo de soja e 4\% de óleo de soja (dieta controle); D1 = Dieta, onde 12,5\% de farelo de soja e $25 \%$ de óleo de soja foram substituídos por RSC; T2 = Dieta, onde $25 \%$ do farelo de soja e $50 \%$ do óleo de soja foram substituídos por RSC; T3 = Dieta, onde 37,5\% do farelo de soja e $75 \%$ do óleo de soja foram substituídos por RSC; e T4 = Dieta, onde $50 \%$ do farelo de soja e $100 \%$ do óleo de soja foram substituídos por RSC. Os resultados demonstraram que em sementes de borracha crua a proporção de kernel para casca é 64: 36. Os componentes próximos do caroço de semente de borracha gordurosa fervida e seca ao sol foram: umidade =96,6\%; EM = $5305 \mathrm{kcal} / \mathrm{kg} \mathrm{MS} ; \mathrm{CP}=17,6 \% ; \mathrm{EE}=$ $51,05 \% ; \mathrm{CF}=8,5 \%$; NFE $=18,25 \%$; e Ash $=4,6 \%$. Os pesos corporais das aves aos 35 dias de idade em todos os tratamentos dietéticos foram estatisticamente semelhantes. O consumo de ração das codornas entre os diferentes grupos dietéticos variou significativamente $(\mathrm{p}<0,05)$ e houve uma tendência de diminuição do consumo de ração em $25 \%$ e acima do nível de inclusão do RSC. O ganho de peso corporal e a FCR também foram estatisticamente semelhantes em todos os grupos dietéticos. O custo da ração e o custo total de produção / $\mathrm{kg}$ de PC de codornas também se tornaram cada vez mais altos $(p>0,05)$ no nível de inclusão de RSC mais alto. Constatou-se que o desenvolvimento muscular melhorou com o nível de RSC mais baixo (\%), enquanto os órgãos aumentaram com a inclusão de RSC mais alta. Os resultados sobre a maioria dos parâmetros de produção e parâmetros econômicos e de rendimento de carcaça sugeriram que a substituição simultânea de no máximo 50\% de óleo de soja e 25\% de farelo de soja por RSC processado pode ser sugerida, particularmente, haverá uma crise na disponibilidade desses dois ingredientes.
\end{abstract}

Palavras-chave: bolo de sementes de borracha, farelo de soja, desempenho de crescimento, codorniz japonesa.

*e-mail: dremmanuelahaotu@hotmail.com

Received: September 5, 2020 - Accepted: October 17, 2020

This is an Open Access article distributed under the terms of the Creative Commons Attribution License, which permits unrestricted use, distribution, and reproduction in any medium, provided the original work is properly cited. 


\section{Introduction}

The poultry industry is one of the fast means of providing the much needed animal protein to the teeming populace. It has been suggested that the expansion of the Nigeria poultry holds the greatest promise of bridging the animal protein gap in the country within the shortest possible time (Ahaotu et al., 2017a). Some agro-industrial by-products like Bambara nut, feather meal, rice offal, brewer's dried grain have been used in poultry diets to replace cereals (Ahaotu, 1999; Ahaotu et al., 2010a, b, 2015, 2016a, b, 2012a, b). Broiler birds are probably the most universal and important of all poultry as producers of meat for human consumption. It has been reported that sweet orange (Citrus sinensis) peel meal obtained from ground sun dried peels can replace dietary maize in broiler chicken diet at $20 \%$ level without any adverse effect on performance (Agu, 2006; Grant, 2007).

Feed processing helps to enhance the feeding quality of agro-industrial by-products by reducing the level of toxicants where present, improving their nutrient value, acceptability of feed, and utilization by animals. The shortage of good quality feeds needed to sustain livestock growth, especially during the dry season has been a major challenge to the industry in the developing countries. Thus crop residues, agro-industrial by products and non-conventional feed resources which abound during the dry season are being evaluated to access their nutritive potential to support livestock productivity.

Several factors have been generally identified as limiting to the utilization or high incorporation of nonconventional feedstuffs in livestock feed. These include low protein content, high fibre, amino acid imbalance and presence of anti-nutritional factors (Mourao et al., 2008). Anti-nutritional factors have significant negative effects on livestock production. These effects include reduction in palatability, digestibility and utilization of ration, intoxication of different classes of livestock, resulting in mortality or decreased production of animal and reduction in the quality of meat, egg, and milk products due to the presence of hazardous residues (Nazok et al., 2010).

There are two sources of feed protein, which are protein of animal origin and plant origin. Animal source protein is obviously the most costly ingredient for the formulation of poultry diets than any other sources of the nutrients. The plant source protein, soybean meal, is also costly ingredient because it is imported from abroad and increases the ultimate feed cost. From the economic point of view, poultry should be supplied with cheaper feed to get maximum return with minimum cost. Poultry production may not be remunerative if costly conventional feeds are not replaced by the cheaper unconventional feeds in the poultry diet. A recent trend has been seen among the poultry nutritionists to explore the unconventional cheaper ingredients towards reducing feed cost to maximize profit from poultry farming. The locally produced one unconventional feed ingredient like rubber seed meal (RSM) may reduce the feed cost.

Now-a-days, RSM has been tasted as a feed ingredient of laboratory animal. It has a good nutritional value having $2520 \mathrm{kcal} / \mathrm{kg}$ energy, 34.10\% crude protein and $10.12 \%$ fat, $3.1 \%$ ash and $4.4 \%$ fiber content (Ahaotu et al. 2012a,b). So, this unconventional feed ingredient can be efficiently used in formulating broiler diet as a protein source. A rubber plant can produce huge amount of seed up to 30 years coupled with its main produce "the rubber". Normally, the amount of seed produced from a rubber plant is several times higher than that of rubber crop produced from the same tree. Throughout the world the rubber seed is using for oil production but in Nigeria no care is taken to use these seeds, and simply becoming wastage. On the other hand, soybean meal is an important protein rich ingredient in poultry feed which is mostly being imported in Nigeria.

The palm oil or soybean oil is also an essential feed ingredient of growing quail, particularly for broiler. Therefore, there is a good scope to test the rubber seed kernel (RS) as a simultaneous replacer of soybean meal and soybean oil at growing quail's diet in Nigeria.

Soybean meal is an excellent source of plant protein, but in Nigeria, it has some limitations for using in poultry diet. Sometimes, it may be contaminated by disease organisms affecting the performance of birds. It is costly due to importing from abroad and ultimately it increases the feed cost. Therefore, it is very important to find out the possibilities of using alternative sources of low cost protein to substitute the expensive soybean meal. A number of works have been done on the effect of replacing soybean meal by unconventional feed ingredients on the performance of poultry, specially chicken .But, the research on the effect of rubber seed meal (RSM) on quail performance are scanty.

Protein rich ingredients in poultry feeding: Ahaotu et al. (2012a,b) reported that the replacement of soya bean by lupin field bean, green pea and a lucerne concentrate in both the starting and finishing diets of broilers caused a decrease in feed conversion efficiency

Need for using the unconventional protein source in Nigeria: In poultry rearing, feed cost alone accounts 65$70 \%$ of the production cost and protein cost accounts $15 \%$ of total feed cost. Animal protein sources and soybean meal are obviously costly for inclusion in poultry diets. Soybean is also a competitive ingredient with fish and other livestock. So, the nutritionists are searching for good quality unconventional plant protein source at a minimum cost with high levels of energy, protein, vitamin and essential minerals to support maximum growth of the bird within a shortest period of time.

Conventional versus unconventional protein rich feed ingredients of poultry feed: The utilization of unconventional feed resources (UCFR) in Asia is justified by serious feed deficits, rising cost of production, low animal productivity, and inability of the components of the animal industries to meet national targets, especially of animal proteins. Constraints to the effective utilization of unconventional feeds are reviewed in the context of characteristics of these feeds, adequacy and requirements, and priorities for used by animals. It is estimated that from field, plantation and tree crops, approximately $238 \mathrm{x}$ 106 tonnes or $46 \%$ of unconventional feeds are produced 
annually (Ahaotu et al., 2010a, b). Of these, about 80-93\% of the feeds produced are suited for feeding ruminants and poultry. Optimum levels of utilizing many of the feed ingredients are summarized as a first step to diet formulation and case studies are cited which demonstrate economic benefits. Limited data are available on deleterious principles of these feeds. The strategies for promoting expanded and intensive use of unconventional feed resources require high emphasis on the utilization of research results involving large scale on-farm testing of the potentially important feedstuffs in individual countries. This initiative merits the highest priority in the objective to maximize productivity from, and more efficient use of, the animal and quail.

Status and use of soybean meal at poultry feed industry in Nigeria: Large, medium, even small commercial poultry farmers are problems in formulating ration as per recommendations for high cost, low quality and variable quality of the conventional feed ingredient, their seasonal availability and improper control over feed market. There are two sources of feed proteins, which are protein of animal and plant origin. Among the animal proteins, fish meals are usually used in the feed. It is obviously costly as a competitor of human being in respect of dry fish consumption and other limitations. Now it has become essential to search for an alternative source of protein to formulate poultry feed. Soybean meal is cheaper as compared to animal proteins, therefore, most of the feed mill in Nigeria is using this ingredient as protein source. In developed countries and soybean meal is being used successfully. The predominance of soybean meal can be attributed to its availability and superior amino acids composition. In Nigeria, soybean meal is mostly imported and the producers are searching its substitute for higher profit.

Past attempts of replacing soybean meal with other plant origin protein ingredients: the rising prices of livestock feeds, especially in Nigeria, and the scarcity of conventional protein and energy concentrates for the formulation of feeds have forced the animal scientists in Nigeria to search for attractive, cheaper and readily available protein and energy sources (Ahaotu, 2011). These efforts have produced accumulating evidence that the alternatives, such as palm kernel cake, Bambara groundnut meal, pigeon pea meal, mango seed kernel meal and rubber seed meal can be used for feeding livestock, especially to poultry, pigs and rabbits with encouraging results (Ahaotu et al., 2011). Rubber seeds are very abundant in the South Eastern States of Nigeria where rubber is produced for domestic purposes and for export. The seeds are usually discarded. In recent years, however, a lot of attention has been paid to rubber seed meal as a potential protein source for livestock, having been reported to have about $41 \%$ crude proteins

It has been noted that significant changes in the blood parameters can be used to assess both the pathological and nutritional status of individual animals (Ahaotu, 2011). It has also been established that certain haematological factors can be associated with certain production traits (Ahaotu et al.2010a, b). Consequently, the effects of any feed ingredient on the haematological indices of chickens are of immense assistance in deciding whether or not such a feed ingredient should be used as poultry feed.

Nutritional value of rubber seed: Rubber seed meal (RS) has been tasted as a feed ingredient of laboratory animal. It has a good nutritional value having $2520 \mathrm{kcal} /$ $\mathrm{kg}$ energy, $34.10 \%$ crude protein and $10.12 \%$ fat, $3.1 \%$ ash and $4.4 \%$ fiber content (Ahaotu et al., 2010a, b). Therefore, he suggested this unconventional feed ingredient to use in formulating broiler diet as a source protein. Three experiments were conducted to evaluate the nutritive value of rubber (Hevea brasiliensis) seed meal either in vivo or in vitro by the pepsin / pancreatin incubation procedure. The average weight of the seed was $3.29 \pm 0.78 \mathrm{~g}$ and the proportion kernel / husk was $1.17 \pm 0.40 \mathrm{~g}$.

The average composition of rubber seed meal was ash 3.10, NDF 53.8, crude fat 28.4 and N 2.39\% in dry basis. The cyanide content of the seeds decreased from 82.5 to $29.3 \mathrm{mg} / \mathrm{kg} \mathrm{DM}$ (dry matter) in approximately 45 days of storage. In vivo digestibility of nutrients of the feed (sugar palm syrup and dried fish) was not impaired by the introduction of either 17.8 or $40.5 \%$ of rubber seed meal in the diet. Digestibility indices of rubber seed meal as estimated by the differences were DM 79.4, NDF 75.0, N2 83.6 and organic matter $85.5 \%$. In vitro digestibility studies indicated significantly $(P<0.001)$ higher values for N2 utilization in the rubber seed kernel (89.7\%) than in fish meal or dried fish (81.3 and $77.2 \%$, respectively). In vitro DM and organic matter digestibility coefficients in the husk were comparatively low, probably due to the fibrous nature of this material.

Present status of production and use of rubber seed: Recently, about 25,000 hectare of land is under rubber plantation in Nigeria and approximately 7,500 tons of rubber is producing every year. A rubber plant can produce huge amount of seed up to 30 years coupled with its main produce "the rubber". Normally, the amount of seed produced from a rubber plant is several times higher than that of rubber crop produced from the same tree. Throughout the world rubber seed is used for oil production but in Nigeria no care is taken to use these seeds and simply becoming wastage. So there is a good scope to test the RSM as a replacer of soybean meal in broiler diet in Nigeria.

Anti-nutritional factors present in rubber seed: Numerous in vitro and in vivo studies have shown that the apparent amino acid digestibility's in rubber seed were reduced by tannins, also it has showed that rubber seed contained tannin which can decline the nitrogen digestibility in chicks (Ahaotu, 2011).

Anti-nutritional factors present in rubber seed: Numerous in vitro and in vivo, studies have shown that the apparent amino acid digestibility's in rubber seed were reduced by tannins, it has showed that rubber seed contained tannin which can decline the nitrogen digestibility in chicks (Godoy \& Batista, 1997).

The digestion of protein was reduced due to the formation of stable complexes with tannins (Godoy \& Batista, 1997). Various attempts have been taken by scientists throughout the world to remove, reduce, and to inactivate the tannin, (both condensed and 
hydrolysable) in rubber seed and other animal feeds. The methods available for removal or inactivation of tannins as complied by Godoy \& Batista (1997) are physical treatment and chemical treatments. Among physical treatments; soaking, cooking and boiling of tannin containing feedstuffs have been found very effective in decreasing the tannin content.

Use of Japanese quail as research animal: Quail (Coturnix coturnix) belongs to the family Phasianidae and order Galliformes under the class Aves of Animal Kingdom. The use of Japanese quail as a laboratory animal was first reported in 1959. Later, the Japanese quail is recommended to interested investigators, especially to embryologists and physiologists, for use in research because of its hardiness, ease of handling, precociousness, and great laying ability (Ahaotu et al., 2017b).

Research gap and the need for the current study: Rubber seed (Hevea brasiliensis) is an unconventional forest byproduct feed ingredients. A number of trials on the use of rubber seed meal has been conducted by the scientists across the world using the array of livestock and wild species. The nutritive value of the rubber seed meal is almost equivalent to that of soybean meal. But the published literatures on the use of full fat rubber seed kernel as a poultry feed ingredient is not so much and this scanty information does not clearly indicate whether this full fat rubber seed is fully toxic or harmless to the birds and exactly what inclusion level is well comparable with others protein / energy sources in diets of different types of poultry.

The full fat rubber seed kernel which has not been subjected to oil extraction contains sufficient (30-40\%) amount of crude oil that can be a source of huge energy too to the growing birds. It is a customary to use the fats or oil in the growing bird's ration to meet their higher energy demand. Therefore, the proposed study was attempted to use the processed full fat rubber seed kernel in the diet of growing Japanese quail as a simultaneous replacer of partial soybean meal and complete replacer of soybean oil. The soybean meal and soybean oil both are imported in Nigeria, but the rubber seed is locally produced and currently, no cost is needed to buy it. Therefore, the findings of this research might guide the poultry producer and feed manufacturer to use this by product efficiently as a feed ingredient to reduce the production cost.

\section{Materials and Methods}

\subsection{Location of study area}

The study was conducted at the Poultry Unit of Imo State Polytechnic Umuagwo. Imo State Polytechnic Umuagwo is located at The site is situated between longitudes $7^{\circ}$ $0^{1} 06^{11} \mathrm{E}$ and $7^{\circ} 03^{1} 00^{11}$ and latitudes $5^{\circ} 28^{1} 00^{11} \mathrm{~N}$ and $5^{\circ}$ $30^{1} 00^{11} \mathrm{~N}$ in the humid tropical West Africa (IMLS, 2009). The climate is marked by two seasons.

\subsection{Sources of Rubber Seed (RS) and processing method}

The rubber seeds used in this study was obtained from the rural women from Iho, Ikeduru Local Government
Area of Imo State. Harvested rubber seeds were carefully selected by hand-picking them from under rubber plantation. Seeds were removed from the shell and oil was extracted with a manually operated rubber seed oil extractor. This was then be spread thinly on a concrete slab to sundry for about a week to reduce moisture content to be less than $7 \%$.

This dry rubber seed was milled into fine powder, packaged and stored in an air-tight polythene bag. This powdered test ingredient was mixed in calculated proportions with other feed ingredients to formulate five experimental diets for the feed trial.

\subsection{Statement of the experiment}

An experiment was carried on with Japanese quail (Cotornix cotornix Japonica) at the Poultry Unit of Imo State Polytechnic Umuagwo. Imo State Polytechnic Umuagwo for a period of 4 weeks. The one-week-old apparently healthy growing quail was used in this experiment as the model animal. The experimental quail was collected from a commercial hatchery in Owerri, Imo State. The 0 to $50 \%$ of the soybean meal and 0 to $0 \%$ of the soybean oil used in the diet of 8-day- to 42-day-old growing Japanese quail have been replaced by processed rubber seed (RS). The feed intake, survivability, growth rate and carcass characteristics of the birds were investigated in this experiment.

\subsection{Data analysis}

Results were expressed as mean values and standard deviation of five (5) determinations. The obtained data was analysed using a one-way analysis of variance (ANOVA) previous homocedasticity and normality verifications using Statistical Packaging for Social Science (SPSS) version 20.0 software 2011 to test the level of significance $(p<0.05)$. Duncan New Multiple Range Test was used to separate the means where significant differences existed (Steel and Torie, 1980).

\subsection{The processing of raw rubber seeds}

The raw RS was processed according to the following procedures specified in Figure 1.

\subsection{Preparation of the experimental diet}

The diets were formulated weekly using the ingredients available at local feed markets. The major ingredients used in the diet were maize, wheat bran, rice polish, mustard oil cake, soybean meal, meat and bone meal (MBM) and protein concentrate-60\%. The maize, palm kernel cake, soybean meal, rubber seed were ground to powder by a hand grinding machine. Then, a thorough mixing was done after weighing of the feed ingredients proportionately for each experimental diet. The vitamin-mineral pre-mix was added according standard procedure. The feed were formulated according to the requirement of growing quail (NRC, 1994) using the ration formulation program in computer. The ingredient composition of the diets is shown in Table 1. 


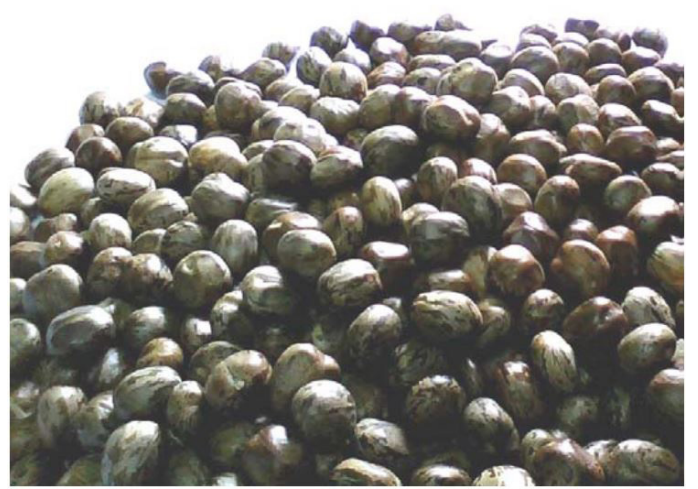

Figure 1. Raw rubber seeds from the plantation.

Table 1. Ingredient Composition of the experimental diets ( $T_{1}$, $\mathrm{T}_{2}, \mathrm{~T}_{3}, \mathrm{~T}_{4}$ and $\mathrm{T}_{5}$ ).

\begin{tabular}{cccccc}
\hline Feed-Ingredients & $\mathbf{T}_{\mathbf{1}}$ & $\mathbf{T}_{\mathbf{2}}$ & $\mathbf{T}_{\mathbf{3}}$ & $\mathbf{T}_{\mathbf{4}}$ & $\mathbf{T}_{\mathbf{5}}$ \\
\hline Maize & 37.0 & 37.0 & 37.0 & 37.0 & 37.0 \\
Broken Sorghum & 5.0 & 5.0 & 5.0 & 5.0 & 5.0 \\
Soya bean meal & 20.0 & 15.0 & 10.0 & 5.0 & 0.0 \\
Rubber seed cake & 0.0 & 5.0 & 10.0 & 15.0 & 20.0 \\
Wheat Bran & 11.0 & 15.0 & 15.0 & 15.0 & 15.0 \\
Palm Kernel Cake & 10.0 & 11.0 & 11.0 & 11.0 & 11.0 \\
Bone Meal & 3.0 & 3.0 & 3.0 & 3.0 & 3.0 \\
Fish Meal & 4.0 & 4.0 & 4.0 & 4.0 & 4.0 \\
Spent Grain & 9.0 & 9.0 & 9.0 & 9.0 & 9.0 \\
Common Salt & 0.25 & 0.25 & 0.25 & 0.25 & 0.25 \\
Methionine & 0.15 & 0.15 & 0.15 & 0.15 & 0.15 \\
Lysine & 0.25 & 0.25 & 0.25 & 0.25 & 0.25 \\
Growers Premix & 0.35 & 0.35 & 0.35 & 0.35 & 0.35 \\
\hline
\end{tabular}

$\mathrm{T} 1, \mathrm{~T} 2, \mathrm{~T} 3, \mathrm{~T} 4$ and $\mathrm{T} 5=$ Treatments.

\subsection{Processing of quails}

At the end of the experiment two quails from each pan were randomly selected and wing banded. The selected birds were slaughtered by "Halal method". After slaughtering, the quails were allowed to bleed completely. The slaughtered quails were manually washed without soaking into water. Final processing was performed by removal of viscera, head, shank, skin, kidney, liver, heart, proventriculus, gizzard of the carcass. The gizzard was opened with a knife and faecal materials were removed to take its actual weight.

\section{Results}

Composition of rubber seed: In mature rubber seed were collected from rural women in Iho, Ikeduru Local Government Area of Imo State. The proportion of kernel to hull was $64: 36$. The dry matter (DM) contents of the kernel and hull were found $96.6 \%$ and $91.8 \%$, respectively.
The metabolizable energy (ME), crude protein $(\mathrm{CP})$, crude fiber $(\mathrm{CF})$, ether extract (EE), nitrogen free extract (NFE) and ash contents of rubber seed kernel (RS) were $5305 \mathrm{kcal} / \mathrm{kg} \mathrm{DM}, 17.6 \%, 8.5 \%, 51.05 \%, 18.25$ and 4.6\%, respectively. The photographs of RS kernel and hull are given in Figures 2, 3 and 4.

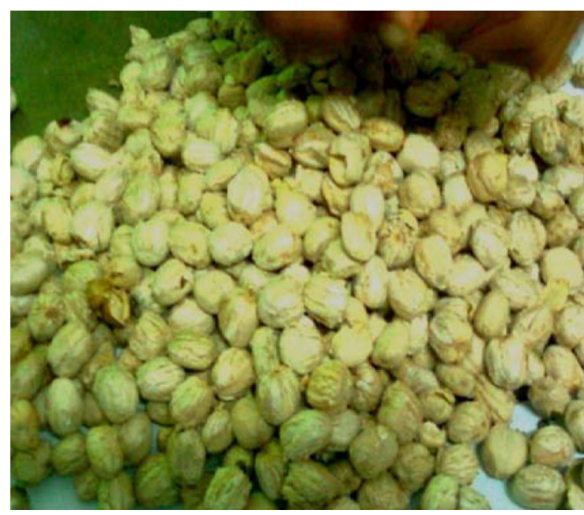

Figure 2. Kernel of rubber seeds.

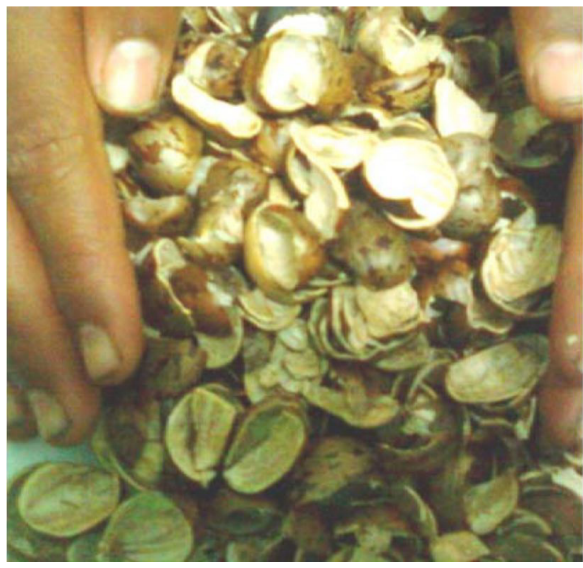

Figure 3. Hull of rubber seeds.

$\square \mathrm{D} 0 \square \mathrm{D} 1 \square \mathrm{D} 2 \square \mathrm{D} 3 \square \mathrm{D} 4$

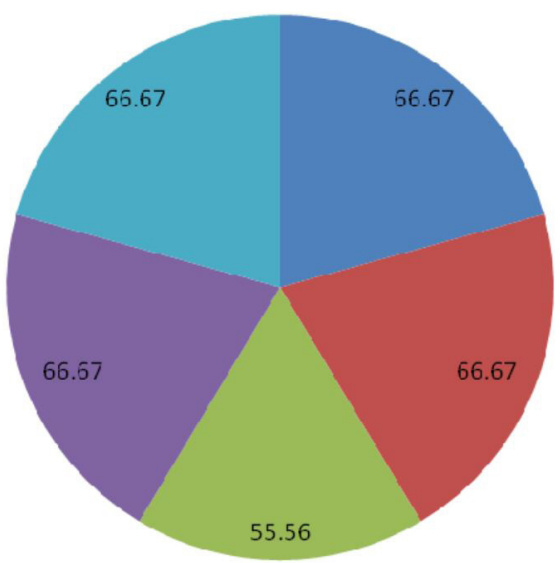

Figure 4. Survivability (\%) of the growing quail under different dietary treatments $\left(\mathrm{D}_{0}, \mathrm{D}_{1}, \mathrm{D}_{2}, \mathrm{D}_{3}\right.$ and $\mathrm{D}_{4}=$ Treatments, see Table 1$)$. 
Effect of RS containing diet on the performance parameters and cost-effectiveness of growing quail: The physical appearance and health condition was found normal in different dietary groups, except the $\mathrm{D}_{3}$, where only one quail was found unable to walk at half way of the experiment. Incidence of only case implied that this might be due to physical injury of the quail rather than any effect of RS. The body weight, body weight gain, feed intake, feed conversion ratio, feed cost and total cost of production of the growing quails on different dietary treatments are presented in Table 2.

Relationship between RS inclusion level in diet and feed intake of growing quail: The weekly feed intake (FI) and the regression of RS inclusion level on FI of the growing quail over time has been presented in Figures 5 and Figures 6 respectively. It was found that the total weekly FI in different dietary groups were not similar at all ages. During the 1st and 2nd week of RSC feeding, the FI was not affected at any level of RSC inclusion. But, on 3rd week of RSC inclusion, was marked decline in FI of the bird on RSC level $25 \%$ and above, which was recovered to that of the control diet later on, except the 12.5 inclusion group that was found to consume more feed at 2 nd week through end of the experiment.

Effect of RS incorporation on carcass composition of growing quail: The carcass composition and carcass yield characteristics of 5-week old quail on different dietary treatments are shown in Table 3. Among the carcass components, the drumstick weight, thigh, wing, liver, kidney, heart, gizzard and head weights were found to be varied among birds fed diets containing various levels of RSC. The dressing percentage (DP) of among the dietary groups was significantly different. The DP became lowered at 37.5 and $50 \%$ RSC included diet when compared with that of the quails of control and other lower level RS added groups. The liver and kidney weights in the quails were found to be higher at higher RSC included in the diet compared to control and other lower RS groups. The thigh and wing weights were markedly lowered at 50\% RSC inclusion that all other dietary groups. The reduction in muscle weight and enlargement of the liver and kidney at relatively higher RSC incorporated diets; particularly at $50 \%$ replacement of soybean meal gives the indication of the presence of toxic substances in RSC.

\section{Discussion}

Ahaotu et al., 2010a, b analyzed the rubber seed (Hevea brasiliensis) and reported the average weight of seed and the kernel to hull ratio to be $3.29 \pm 0.78 \mathrm{~g}$ and 1.17 , respectively. The observed DM \% of RS in the current study was almost coincided with that of the soybean meal.

The CF level in the sample was $8.5 \%$, which was nearly similar to that reported. They had reported that the RS contains 3.1 to $5 \% \mathrm{CF}$. The ME value of RS of this study is approximately double to that found in RSM and soybean meal. The ash content of RS was also very close to that of other plant protein sources. Therefore, considering the

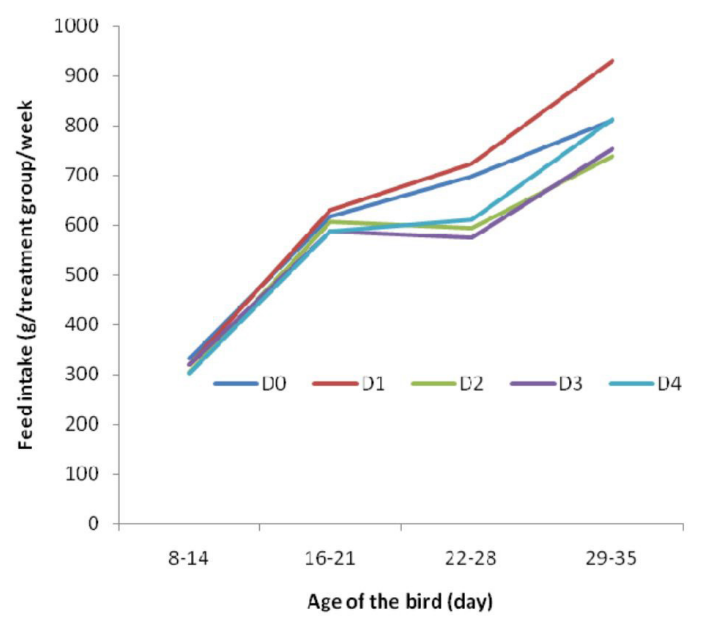

Figure 5. Feed intake of the bird under different dietary treatment at different ages $\mathrm{D}_{0}, \mathrm{D}_{1}, \mathrm{D}_{2}, \mathrm{D}_{3}$ and $\mathrm{D}_{4}=$ Treatments, see Table 1 .

Table 2. Performance of the growing Japanese quail during 2-5 week of age fed on RS added diet.

\begin{tabular}{|c|c|c|c|c|c|}
\hline Parameters LOS & $T_{1}$ & $\mathbf{T}_{2}$ & $T_{3}$ & $\mathbf{T}_{4}$ & $\mathbf{T}_{5}$ \\
\hline $\begin{array}{l}5^{\text {th }} \text { Week BW } 8.22 \\
\text { n.s }\end{array}$ & $119.60 \pm 2.56$ & $128.00 \pm 6.72$ & $112.10 \pm 6.34$ & $123.20 \pm 3.74$ & $131.30 \pm 8.01$ \\
\hline $\begin{array}{l}\text { BWG (\% of IBW) } \\
26.85 \text { n.s }\end{array}$ & $162.90 \pm 12.23$ & $148.20 \pm 17.11$ & $120.60 \pm 12.56$ & $147.10 \pm 16.46$ & $145.40 \pm 13.5$ \\
\hline $\mathrm{FI}(\mathrm{g} / \mathrm{b} / \mathrm{d}) 0.32^{*}$ & $9.80 \pm 0.09^{a, b}$ & $10.30 \pm 0.11^{\mathrm{b}, \mathrm{c}}$ & $8.90 \pm 0.13^{b, c}$ & $8.90 \pm 0.09^{b, c}$ & $8.80 \pm 0.19^{b, c}$ \\
\hline $\begin{array}{l}\text { FCR }\left(2^{\text {nd }} \text { to } 5^{\text {th }}\right. \\
\text { week }) 1.27 \text { n.s }\end{array}$ & $1.87 \pm 0.36$ & $2.10 \pm 0.42$ & $2.12 \pm 0.45$ & $3.40 \pm 0.67$ & $3.71 \pm 0.78$ \\
\hline $\begin{array}{l}\mathrm{FC}(\mathrm{BDT} / \mathrm{kgBW}) \\
27.33 \text { n.s }\end{array}$ & $54.40 \pm 12.56$ & $56.00 \pm 11.67$ & $52.90 \pm 8.78$ & $78.00 \pm 17.20$ & $77.50 \pm 14.50$ \\
\hline TC (BDT/kgBW) & $221.60 \pm 7.56$ & $212.20 \pm 12.50$ & $230.90 \pm 20.56$ & $240.00 \pm 22.15$ & $229.70 \pm 15.59$ \\
\hline
\end{tabular}

Values (mean \pm standard error) bearing the uncommon superscripts differ significantly $(p<0.05$ ); SED = Standard error differences; BW= Body weight (g/bird); FCR= Feed conversion ration; FI (g/b/d) = Feed intake (g/bird/day); BWG= Body weight gain; IBW= Initial body weight; BDT= Nigerian Naira; TC= Total cost; D0= Diet containing $20 \%$ soybean meal and $4 \%$ soybean oil (control diet), D1= Diet, where $12.5 \%$ of soybean meal and $25 \%$ of soybean oil has been replaced by RS; T2 = Diet, where $25 \%$ of soybean meal and $50 \%$ of soybean oil has been replaced by RS; T3 = Diet, where $37.5 \%$ of soybean meal and $75 \%$ of soybean oil has been replaced by RS; T4 = Diet, where $50 \%$ of soybean meal and $100 \%$ of soybean oil has been replaced by RS; T1, T2, T3, T4 and T5 = Treatments;.n.s. = non significant differences. 


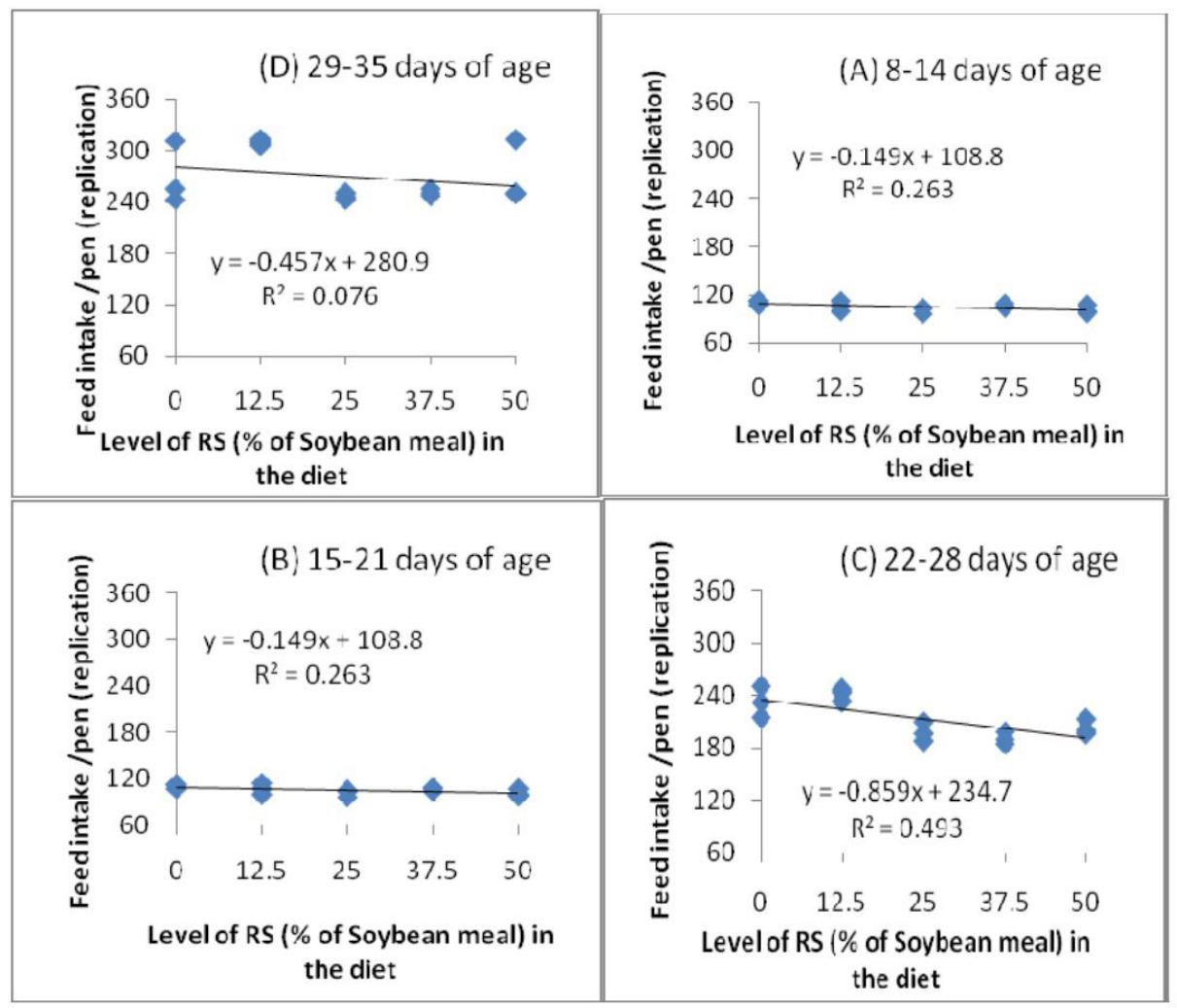

Figure 6. Regression for the equation of, $y=a+b x$; where, $y=$ feed intake, $x=$ the inclusion rate of RS in the diet in place of soybean meal, and $b=$ regression co-efficient and $a=$ intercept. D0= Diet containing $20 \%$ soybean meal and $4 \%$ soybean oil (control diet), D1= Diet, where $12.5 \%$ of soybean meal and $25 \%$ of soybean oil has been replaced by RS; D2 = Diet, where $25 \%$ of soybean meal and $50 \%$ of soybean oil has been replaced by RS; D3 = Diet, where $37.5 \%$ of soybean meal and $75 \%$ of soybean oil has been replaced by RS; D4 = Diet, where $50 \%$ of soybean meal and $100 \%$ of soybean oil has been replaced by RS.

Table 3. Carcass composition in 35 days old Japanese quail in different dietary treatments.

\begin{tabular}{|c|c|c|c|c|c|c|c|}
\hline \multirow{2}{*}{$\begin{array}{c}\text { Parameters } \\
\text { LOS }\end{array}$} & \multicolumn{5}{|c|}{ Diets } & \multirow{2}{*}{ SED } & \multirow{2}{*}{ LOS } \\
\hline & $T_{1}$ & $T_{2}$ & $T_{3}$ & $T_{4}$ & $T_{5}$ & & \\
\hline Dressing \% & $9.93 \pm 0.69$ & $67.71 \pm 1.19$ & $66.19 \pm 0.72$ & $69.63 \pm 1.10$ & $69.45 \pm 0.79$ & 1.317 & * \\
\hline Back wt \% & $11.03 \pm 0.16$ & $10.58 \pm 0.30$ & $12.16 \pm 1.07$ & $11.13 \pm 0.46$ & $11.59 \pm 0.82$ & 0.910 & n.s \\
\hline Breast wt \% & $24.23 \pm 0.52$ & $22.01 \pm 0.36$ & $24.18 \pm 0.91$ & $22.50 \pm 0.71$ & $23.91 \pm 0.81$ & 0.967 & n.s \\
\hline $\begin{array}{l}\text { Drumstick } \\
\text { wt } \%\end{array}$ & $5.22 \pm 0.14$ & $4.89 \pm 0.66$ & $5.74 \pm 0.29$ & $5.40 \pm 0.08$ & $5.63 \pm 0.11$ & 0.223 & $*$ \\
\hline Feather wt \% & $4.89 \pm 0.16$ & $5.84 \pm 0.28$ & $5.56 \pm 0.63$ & $5.94 \pm 0.65$ & $6.09 \pm 0.36$ & 0.704 & n.s \\
\hline $\begin{array}{l}\mathrm{TC}(\mathrm{BDT} / \\
\mathrm{kgBW})\end{array}$ & $221.60 \pm 7.56$ & $\begin{array}{c}212.20 \pm \\
12.50\end{array}$ & $\begin{array}{c}230.90 \pm \\
20.56\end{array}$ & $\begin{array}{c}240.00 \pm \\
22.15\end{array}$ & $\begin{array}{c}229.70 \pm \\
15.59\end{array}$ & 0.646 & n.s \\
\hline Gizzard wt\% & $3.05 \pm 0.19$ & $3.68 \pm 0.10$ & $3.93 \pm 0.16$ & $3.11 \pm 0.07$ & $3.07 \pm 0.15$ & 0.204 & n.s \\
\hline Head wt\% & $4.96 \pm 0.15$ & $4.18 \pm 0.21$ & $4.79 \pm 0.25$ & $4.52 \pm 0.08$ & $4.31 \pm 0.13$ & 0.244 & $*$ \\
\hline Heart wt\% & $0.88 \pm 0.05$ & $77.00 \pm 0.03$ & $1.28 \pm 0.11$ & $72.00 \pm 0.03$ & $77.00 \pm 0.03$ & 0.791 & $* *$ \\
\hline Blood wt\% & $4.13 \pm 0.13$ & $5.71 \pm 0.81$ & $4.87 \pm 0.27$ & $4.55 \pm 0.24$ & $4.41 \pm 0.15$ & 0.584 & n.s \\
\hline Liver wt\% & $2.68 \pm 0.14$ & $3.42 \pm 0.12$ & $3.82 \pm 0.22$ & $3.08 \pm 0.07$ & $0.95 \pm 0.29$ & 0.265 & $*$ \\
\hline
\end{tabular}

Raw RS from rubber garden. Separation of seed kernel from the hulls manually using small hammer. Boiling of the of the seed at $80-90^{\circ} \mathrm{C}$ for 1 hour Sun drying of the boiled seed to reduce the moisture level to 8-10\%. Grinding of the seed to powder by hand grinding machine $\left(T_{1}, T_{2}, T_{3}\right.$, $\mathrm{T}_{4}$ and $\mathrm{T}_{5}=$ Treatments; n.s. = non significant differences; ${ }^{*}$ significant differences lower than $\mathrm{P}<0.05$; ${ }^{* *}$ significant differences lower than $\mathrm{P}<$ 0.01 . 
overall chemical composition it can be said that the RS can be efficiently used as a moderate source of $\mathrm{CP}$ and simultaneously, it might complement the sole energy source oil, animal fat or vegetables fats that are normally being used in the broiler diets throughout the world.

The statistically similar body weight of the quails (Table 2) at 35 days of age in all dietary treatments irrespective of the levels of RS incorporated indicated that the RS might support the growth of the quail as the soybean meal did. The feed intake of the quails among different dietary groups varied significantly ( $p$ $<0.05$ ). The highest feed intake was noticed in $D_{1}$ diet followed by $D_{0}, D_{2}, D_{3}$ and $D_{4}$, and there was a tendency of decreasing the feed intake at $25 \%$ and above inclusion level of RS. The reasons of unexpectedly higher feed intake of $D_{1}$ dietary group are not clear, but there are reports that higher the inclusions of RSM in broiler diet lower the feed intake.

The BWG and FCR were also statistically similar in all dietary groups. The rate of BWG was found to be declined consistently with the higher inclusion of RS. But, the FCR value was tended to be higher at higher RS inclusion. Possibly, the opposite trends between BW and FI, which are the key elements of FCR calculation, might result the tendency of higher FCR at higher RS inclusion. The feed cost and total production cost $/ \mathrm{kg}$ BW was also found to be steadily higher ( $p>0.05$ ) at higher RSC inclusion level. In spite of lower cost $/ \mathrm{kg}$ of the RSC included diet, such tendency could be the consequence of poor FCR in RSC included diet. The mortality rate was statistically similar on all diets. However, it was noticeable that all most $1 / 3$ of the quails were died on all groups irrespective of $\mathrm{RS}$ inclusion. This rate of mortally was coincided with the findings of Ahaotu et al., (2010a,b) who observed a normal mortality rate of 12 to 35 in different colour mutations of Japanese quail.

The regression analysis of RSC level on FI over duration of feeding revealed that the negative regression co-efficient was lower $(b=-0.149)$ during 1 st and 2 nd week of RSC inclusion that became highest $(b=-0.859)$ at 3rd week of feeding that was tended to be lower $(b=-0.458)$ at 4 th week of feeding. However, the depression in 2 nd week FI might be the consequences of temporary negative effect of RSC on bird's FI physiology.

As conclusion, partial replacement of soybean meal up to $50 \%$ and soybean oil up to $100 \%$ by processed RSC in corn-based growing quail diets is not harmful in respect of all parameters measured. But the most of the production parameters, economics and carcass yield parameters indicated that replacement of $50 \%$ soybean oil and soybean meal up to $25 \%$ by processed RSC could cushion unavailability of soybean meal and soybean oil.

\section{Acknowledgements}

The present study was founded by project MECESUP UCT 0804 and the authors express their gratitude to M.I. and S.M.A. for their valuable comments for improve the manuscript.

\section{References}

AGU, P.N., 2006. Nutritional Evaluation of sweet orange (Citrus sinensis) Peel as a Feed Resource in Broiler production. Nigeria: Department of Animal Production, University of Agriculture, 100 p. M.Sc. Thesis in Agronomy.

AHAOTU, E.O., 1999. Replacement value of Rubber seed cake for Groundnut cake on the performance of broiler chicks from 0-9 weeks of age. Owerri, Nigeria: Imo State University, 100 p. M.Sc. Thesis in Agronomy.

AHAOTU, E.O., 2011. Effects of dietary substitution of rubber seed cake for groundnut cake on the gross morphology and body conformations of broiler birds. Animal Production Research Advances, vol. 7, no. 2, pp. 69-73.

AHAOTU, E.O., EKENYEM, B.U., AGIANG, E.A., BALAKRISHNAN, V. and MADUBUIKE, F.N., 2010a. Effects of dietary substitution of rubber seed cake for groundnut cake on the body conformations of finisher broilers. Animal Production Research Advances, vol. 6, pp. 44-47.

AHAOTU, E.O., GUANG-HAI, Q., EKENYEM, B.U., KORIE, A.U. and MADUBUIKE, F.N., 2010b. Replacement value of feather meal for fish meal on the performance of Starter Cockerels. Animal Production Advances, vol. 6, pp. 48-52.

AHAOTU, E.O., OGBUOKIRI, U.D.E., KORIE, A.U., EKENYEM, B.U., ONWUKA, C.F.I., OKOLI, I.C., NJOKU, P.O., NDUBUISI, E.C. and MADUBUIKE, F.N., 2011. Effects of graded levels of pigeon pea meal on growth performance and organ characteristics of finisher broilers. Animal Production Research Advances, vol. 7, no. 2, pp. 125-129.

AHAOTU, E.O., EHIRIM, V.I., NKWOCHA, G.A., IWUANYANWU, U.P. and IHEZUO, J.P. 2012a. Carcass and performance characteristics of Khaki Campbell Ducklings fed high fiber rice milling waste. In: Proceedings of the 17th Annimal Conference Animal Science Association of Nigeria, 9-13 September 2012, Abuja. Nigeria: ASAN, pp. 326-329.

AHAOTU, E.O., EDIH, M.C., ONURUKA, A.U., EHIRIM, V.I. and SIRIMONGKOLKASEN, A., 2012b. Effects of replacement of soyabean (Glycine max) with pigeon pea (Cajanus cajan) in starter broiler ration. International Journal of Tropical Agriculture and Food Systems, vol. 6, pp. 40-44.

AHAOTU, E.O., ADEYEYE, S.A. and OKONKWO, V.N., 2015. Replacement value of sweet orange (Citrus sinensis) peels for wheat offals in the performance of broiler starter diets. Scientific Journal of Animal Sciences, vol. 4, pp. 42-50.

AHAOTU, E.O., OKONKWO, V.N., OKORIE, K.C. and AKINFEMI, A., 2016a. Effect of bambara nut sievate supplemented exogenous enzymes on haematology and serum biochemical value of finisher broiler birds. In: Proceedings of Academic Conference on Positioning Sub-Saharan Africa for Development in the New Development, 22-23 June 2016, Accra, Ghana. Legon, Accra: University of Ghana, vol. 9, pp. 32-39.

AHAOTU, E.O., OKONKWO, V.N., IHENACHO, R.A. and EBOCHUO, V.C., 2016b. Performance and carcass characteristics of finisher broilers fed Brewer's dried grain supplemented with Exogenous Enzymes. In: Proceedings of Academic Conference on Positioning Sub-Saharan Africa for Development in the New Development, 22-23 June 2016, Accra, Ghana. Legon, Accra: University of Ghana, vol. 9, pp. 200-208.

AHAOTU, E.O., EKENYEM, B.U. and AGGREY, E., 2017a. Sustainability of sweet orange (Citrus sinensis) peel meal on the performance of finisher Broilers. Journal of Agricultural Sciences Practices, vol. 2, no. 2, pp. 27-32. http://dx.doi.org/10.31248/JASP2016.029.

AHAOTU, E.O., NZE, C.N., AHAOTU, E.O. and AMALAHU, A., 2017b. Nutritional evaluation of graded levels of unripe plantain peel 
(Musa paradisca) meal on the performance of grower Japanese quails (Coturnix). In: Proceedings of the 42nd Conference Nigerian Society for Animal Production, 26-30 March 2017, Nigeria. Shika: NSAP, pp. 487-490.

GODOY, R. and BATISTA, L.A., 1997. Study of the tannin content of forage pigeon pea (Cajanuscajan) germplasm. Revista Brasileira de Zootecnia, vol. 26, pp. 443-446.

GRANT, E., 2007. Citrus world. Angus Journal, pp. 234-238.

IMO STATE MINISTRY OF LANDS AND SURVEY - IMLS, 2009. Longitudes and Latitudes locations of Umuagwo. Nigeria, Ohaji: Egbema Local Government Area of Imo State.

MOURÃO, J.L., PINHEIRO, V.M., PRATES, J.A.M., BESSA, R.J.B., FERREIRA, L.M.A., FONTES, C.M.G.A. and PONTE, P.I.P., 2008. Effect of dietary dehydrated pasture and citrus pulp on the performance and meat quality of broiler chickens. Poultry Science, vol. 87, no. 4, pp. 733-743. http://dx.doi.org/10.3382/ ps.2007-00411. PMid:18339996.

NATIONAL RESEARCH COUNCIL - NRC, 1994. Nutrient requirements of poultry. 9th ed. Washington, DC: The National Academies Press.

NAZOK, A., REZAEI, M. and SAYYAHZADEH, H., 2010. Effect of different levels of dried citrus pulp on performance, egg quality, and blood parameters of laying hens in early phase of production. Tropical Animal Health and Production, vol. 42, no. 4, pp. 737-742. http://dx.doi.org/10.1007/s11250-009-9481-x. PMid:19882229.

STEEL, R.G. and TORRIE, J.H., 1980. Principles and procedures of statistics: a biometrical approach. 3rd ed. USA: McGraw - Hill Book Coy. 